\title{
A first notice of the goniodromitid crab from the Cenomanian (Upper Cretaceous) cold seep deposits of Hokkaido, Japan, with the redescription of Sabellidromites inflata (Collins and Karasawa, 1993) (Decapoda: Goniodromitidae)
}

Primer reporte de un cangrejo goniodromítido en los depósitos de emanaciones frías del Cenomaniano (Cretácico Superior) en Hokkaido, Japón, con la redescripción de Sabellidromites inflata (Collins y Karasawa, 1993) (Decapoda: Goniodromitidae)

Hiroaki Karasawa ${ }^{1, *}$, Manabu Kano²

Mizunami Fossil Museum, Yamanouchi, Akeyo, Mizunami, Gifu 509-6132, Japan.

${ }^{2}$ Mikasa City Museum, 1-212-1, Nishikicho, Ikushumbetsu, Mikasa City, Hokkaido 0682111, Japan.

* Corresponding author: (H. Karasawa) gha06103@nifty.com

\begin{abstract}
Goniodromites sp. (Brachyura: Dromiacea: Goniodromitidae) is described from the Cenomanian (Upper Cretaceous) cold seep sediment in the Middle Yezo Group of Hokkaido, Japan. This species is the first recognition of the genus and family from the Cretaceous chemosynthetic communities, and represents the second record of a decapod from the fossil chemosynthetic communities in Japan. In addition, Sabellidromites inflata (Collins and Karasawa, 1993), a poorly known goniodromitid crab is redescribed.
\end{abstract}

Keywords: Decapoda, Brachyura, Goniodromitidae, cold seep, Gretaceous, Japan.

\section{RESUMEN}

Se describe al Goniodromites sp. (Brachyura: Dromiacea: Goniodromitidae) del Cenomaniano (Cretácico Superior) con sedimentos de los sumideros fríos del Grupo Yezo Medio en Hokkaido, Japón. Esta especie es el primer reconocimiento del género y familia para las comunidades quimiosintéticas del Cretácico, y representa el segundo registro de un decápodo de las comunidades quimiosintéticas fósiles en Japón. Además, se redescribe el Sabellidromites inflata (Collins y Karasawa, 1993), un cangrejo goniodromítido poco conocido.

Palabras clave: Decapoda, Brachyura, Goniodromitidae, sumideros fríos, Cretácico, Japón.

\footnotetext{
How to cite this article:

Karasawa, H., Kano, M., 2021, A first notice of the goniodromitid crab from the Cenomanian (Upper Cretaceous) cold seep deposits of Hokkaido, Japan, with the redescription of Sabellidromites inflata (Collins and Karasawa, 1993) (Decapoda: Goniodromitidae): Boletín de la Sociedad Geológica Mexicana, 73 (3), A020121. http://dx.doi.org/10.18268/ BSGM202lv73n3a020121
} 


\section{Introduction}

Callianassa s.l. hayanoi Karasawa, 2011, was the first decapod described from the Upper Albian chemosynthetic community of Hokkaido. The purpose of the present note is to describe the goniodromitid crab from the Cenomanian cold seep deposit of Hokkaido. This is the second record of a decapod from the fossil chemosynthetic communities of Japan.

The specimen described herein was collected from limestone of the Cenomanian Tenkaritoge Formation of the Middle Yezo Group exposed at Loc. R3013 (Figure 1A) of Tanabe et al. (1977) (=Loc. OB42095 of Funaki and Hirano, 2004) of the Kanajirisawa Creek, Obira-cho, northwestern Hokkaido. In this locality, Kanie et al. (1996) first found the chemosynthetic mollusks and Kanie and Kuramochi (1996) described two chemosynthetic pelecypods, Thracia yezoensis Kanie and Kuramochi, 1996 (as Amanocina yezoensis by Kiel, 2013) and Miltha sp.

The subsequent workers (i.e., Kaim et al., 2008; Kiel et al., 2008) called it the Kanajirisawa seep and reported additional mollusks representing a cold seep-dependent chemosynthetic community. Ogihara $(2005 ; 2008)$ recognized the limestones as cold-seep carbonate rocks based upon biomarker analyses and the significant depletion of $\delta^{13} \mathrm{C}$ values vs $\mathrm{PDB}$ $(-43.4--39.9 \%)$.

The stratigraphic horizon of the limestone is the Upper Cretaceous (middle Cenomanian) by the presence of Desmoceras japonicum Yabe, 1904, and Turrilites sp. cfr. T. acutus Passy, 1832 (Tanabe et al., 1977; Kanie et al., 1996; Funaki and Hirano, 2004).

Furthermore, Sabellidromites inflata (Collins and Karasawa, 1993), a poorly known species of Goniodromitidae Beurlen, 1932, is redescribed based upon the newly collected specimen as well as the type specimen.

The specimens described herein are deposited in the Mikasa City Museum (MCM) and the Mizunami Fossil Museum (MFM).

\section{Systematic paleontology}

Family Goniodromitidae Beurlen, 1932

Genus Goniodromites Reuss, 1858

Type species: Goniodromites bidenatus Reuss, 1858, by subsequent designation of Glaessner (1929).

Included species: See Klompmaker et al. (2012).

Goniodromites sp.

Figures 2A-2D

Examined material: MCM-M395, carapace (length, $4.5 \mathrm{~mm}$; width, $4.3 \mathrm{~mm}$ ) from Loc. R3013 (Figure 1A) of Tanabe et al. (1977), Kanajirisawa Creek, Obira-cho, Hokkaido; limestone of the Tenkaritoge Formation of the Middle Yezo Group (middle Cenomanian); collected by M. Kano.

Description: Carapace small, pentagonal in outline, about as long as wide, widest at about outer orbital angle, narrowed anteriorly and posteriorly, moderately convex longitudinally and transversely. Fronto-orbital width equal to maximum carapace width. Front downturned, strongly protruded anteriorly; frontal margin about $40 \%$ maximum width, composed of two rounded lobes, very weakly notched medially, continuous with upper orbital margin. Upper orbital margin long, nearly straight, oblique to obtuse outer orbital angle. Lateral margins slightly sinuous, tapered posteriorly, with cervical and branchiocardiac incisions. Posterior margin sinuous, weakly concave medially; width about $55 \%$ maximum width. Frontal region with shallow median sulcus. Protogastric regions defined by subtle grooves. Pyriform mesogastric region and narrow anterior mesogastric process, separated from protogastric regions by subtle grooves. Hepatic and protogastric regions not differentiated. Cervical groove well defined; axial element broadly V-shaped; lateral elements nearly straight. Cardiac region defined by broad grooves laterally. Branchiocardiac groove well defined, lateral elements nearly parallel those of cervical groove. Meso- and metabranchial regions not differentiated. 


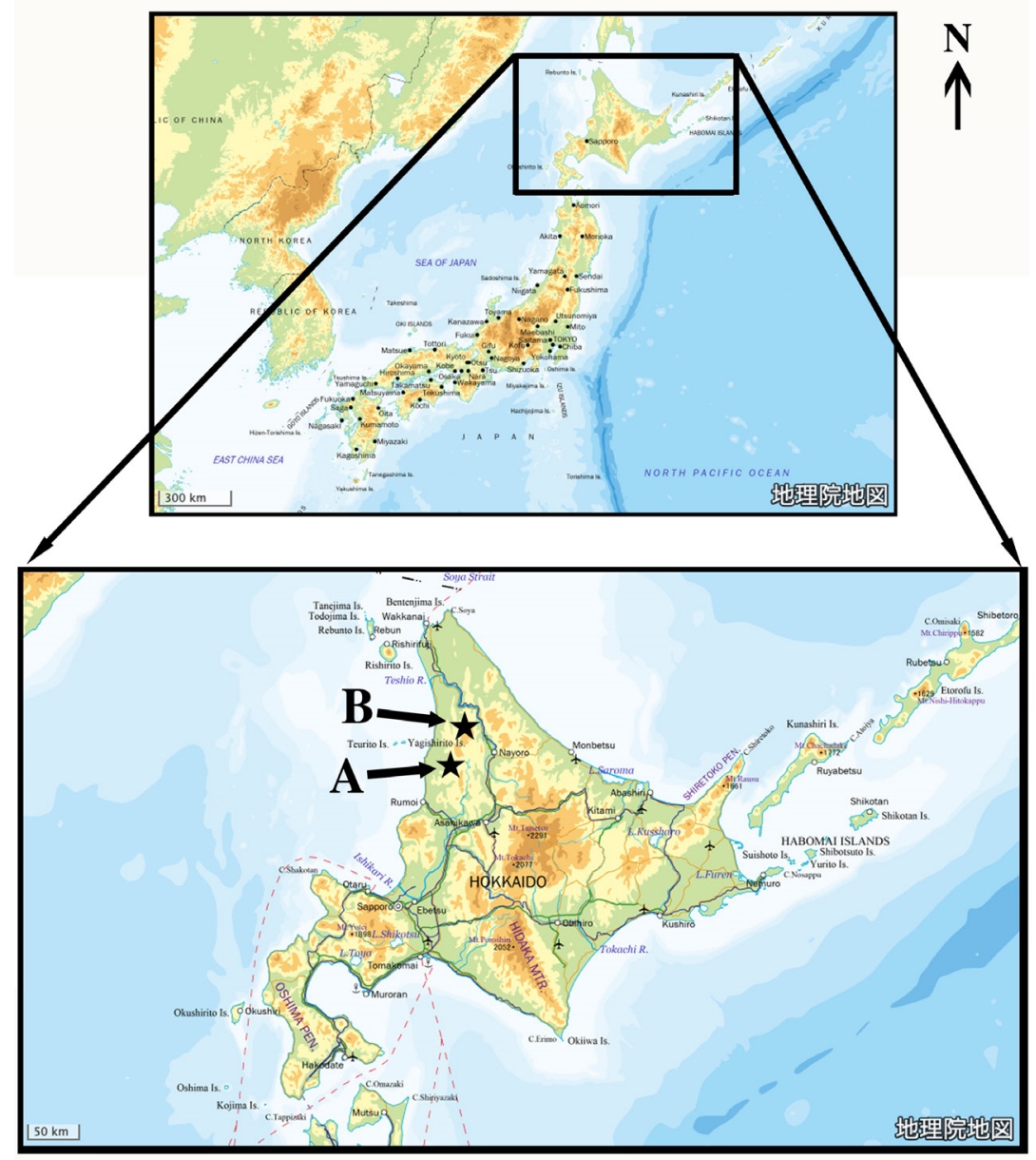

Figure 1 Map showing the fossil-bearing localities. (A); Goniodromites sp., (B); Sabellidromites inflata (Collins and Karasawa, 1993). The map is derived from the Geospatial Information Authority of Japan (http://geolib.gsi.go.jp/).

Discussion: The studied specimen is assigned to Goniodromites in having a pentagonal carapace being about as long as wide, the well-marked cervical and branchiocardiac grooves, and the posteriorly converged lateral margins.

Detailed characters of the dorsal carapace are not known because of lacking most cuticles of the carapace. Since it is difficult to compare the studied specimen among the known fossil species of the genus, we prefer to leave it in open nomenclature.

The hitherto known species of Goniodromites have been recorded from the Jurassic and Cretaceous deposits of Europe, except for two Jurassic species from Japan (Schweitzer and Feldmann,
2008; Schweitzer et al., 2012; Klompmaker et al., 2012); therefore, Goniodromites sp. represents the first record of the genus from the Cretaceous deposits of the North Pacific realm.

The oldest record of decapods from the fossil chemosynthetic communities seems to be part to the Jurassic of France (Campbell, 2006).

Knowledge on decapods from the fossil chemosynthetic communities has been poor (see Karasawa, 2011). Later, new records from the Cenozoic increased (i.e., Kiel and Hansen, 2015; Hryniewicz et al., 2019; Kiel et al., 2020), whereas decapods from the Cretaceous have been extremely rare. 
Bishop and Williams (2000) recorded four brachyurans, Heus foeresteri Bishop and Williams, 2000, Heus manningi (Bishop and Williams, 2000), Konidromites bjorki (Bishop and Williams, 2000), and Hoplitocarcinus? punctatus (Rathbun, 1917), from the Campanian (Upper Cretaceous) cold seep sediment of South Dakota and Colorado, U.S.A. Karasawa (2011) described Callianassa s.l. hayanoi, an axiidean from the upper Albian (Lower Cretaceous) cool seep sediment of Hokkaido. Agirrezabala et al. (2013) reported Callianassa sp. from the upper Albian methane-seep carbonates of Spain. Goniodromites sp. is the first recognition of the genus and family from the Upper Cretaceous chemosynthetic communities. However, most species of Goniodromites have been reported from the Jurassic and Cretaceous coral-reefal sediments of Europe (Schweitzer and Feldmann, 2007; Klompmaker et al., 2012) and only two species have been known from shale of the Upper Jurassic Torinosu Group of Japan (Karasawa and Kato, 2007). Therefore, it is not clear whether Goniodromites sp. represented by only one specimen had been a chemosynthetic-dependent species during the depositional period or the studied specimen had been exceptionally preserved in the sediments.

Genus Sabellidromites Schweitzer and Feldmann, 2007

Type species: Goniodromites scarabaeus Wright and Wright, 1950, by original designation.

Included species: Sabellidromites inflata (Collins and Karasawa, 1993); S. lanae Nyborg, Garassino, and Ross, 2020; S. scarabaea (Wright and Wright, 1950).

Sabellidromites inflata (Collins and Karasawa, 1993)

Figures 2E-2J

Pithonoton inflatum Collins and Karasawa, 1993: 17, fig. $1 \mathrm{a}^{-} \mathrm{c}$.

Pithonoton inflatum-Collins et al., 1993: 295, fig. 2-1a-c.

Sabellidromites inflata-Schweitzer and Feldmann, 2007: 136-Schweitzer et al., 2010: 60.
Examined material: MFM247135, carapace (length $27.7 \mathrm{~mm}$; width, $24.8 \mathrm{~mm}$ ) from YEZ-20 (Figure 1B) of Karasawa and Hayakawa (2000), Wakkauenbetsugawa, Nakagawa-cho, Hokkaido; Osoushinai Formation (lower Campanian) of the Upper Yezo Group (Takahashi et al., 2003, modified from Osanai et al., 1960); collected by K. Masuda.

Emended diagnosis: Carapace rounded-pentagonal, slightly longer than wide, strongly vaulted longitudinally and transversely; frontal margin composed of two triangular lobes; lateral margins gently convex, converged posteriorly, with two low, broad teeth anterior to cervical notch and two more between cervical and branchiocardiac notches; dorsal regions with scattered tubercles; anterior mesogastric process well marked; urogastric region quadrate, depressed; cardiac region elongate-pentagonal with weak, transverse, tuberculated ridge anteriorly; cervical groove deep; epibranchial regions with tuberculated ridge parallel to cervical groove; branchiocardiac groove well defined.

Emended description: Carapace rounded-pentagonal in outline, slightly longer than wide, maximum width about $90 \%$ maximum length, widest at about mid-length, strongly vaulted longitudinally and transversely. Fronto-orbital width about two-thirds maximum carapace width. Frontal margin protruded anteriorly, strongly downturned, rimmed, composed of two triangular lobes, with V-shaped median sulcus. Orbit ovate, oblique; upper orbital margin continuous with frontal margin, nearly straight, rimmed, with blunt outer orbital angle.

Lateral margins gently convex, converged posteriorly; two low, broad teeth present anterior to cervical notch and two more between cervical and branchiocardiac notches. Posterior margin nearly straight, wide, about $60 \%$ maximum carapace width. Frontal region with deep median sulcus. Dorsal regions with scattered tubercles. Epigastric regions vaulted, united with protogastric regions. Anterior mesogastric process well defined; mesogastric region kite-shaped, inter- 
rupted medially, barely differentiated from protogastric regions. Hepatic and protogastric regions not differentiated. Metagastric region depressed posteriorly. Urogastric region quadrate, depressed. Cardiac region elongate-pentagonal in outline, weakly delimited from meta- and mesobranchial regions, with weak, transverse, tuberculated ridge anteriorly, interrupted medially. Intestinal region small, concave medially. Cervical groove deep; lateral elements nearly straight; axial element concave. Epibranchial regions with tuberculated ridge parallel to cervical groove. Branchiocardiac groove well defined, lateral elements nearly parallel those of cervical groove, weakened medially, deepest laterally. Meso- and metabranchial regions not differentiated.

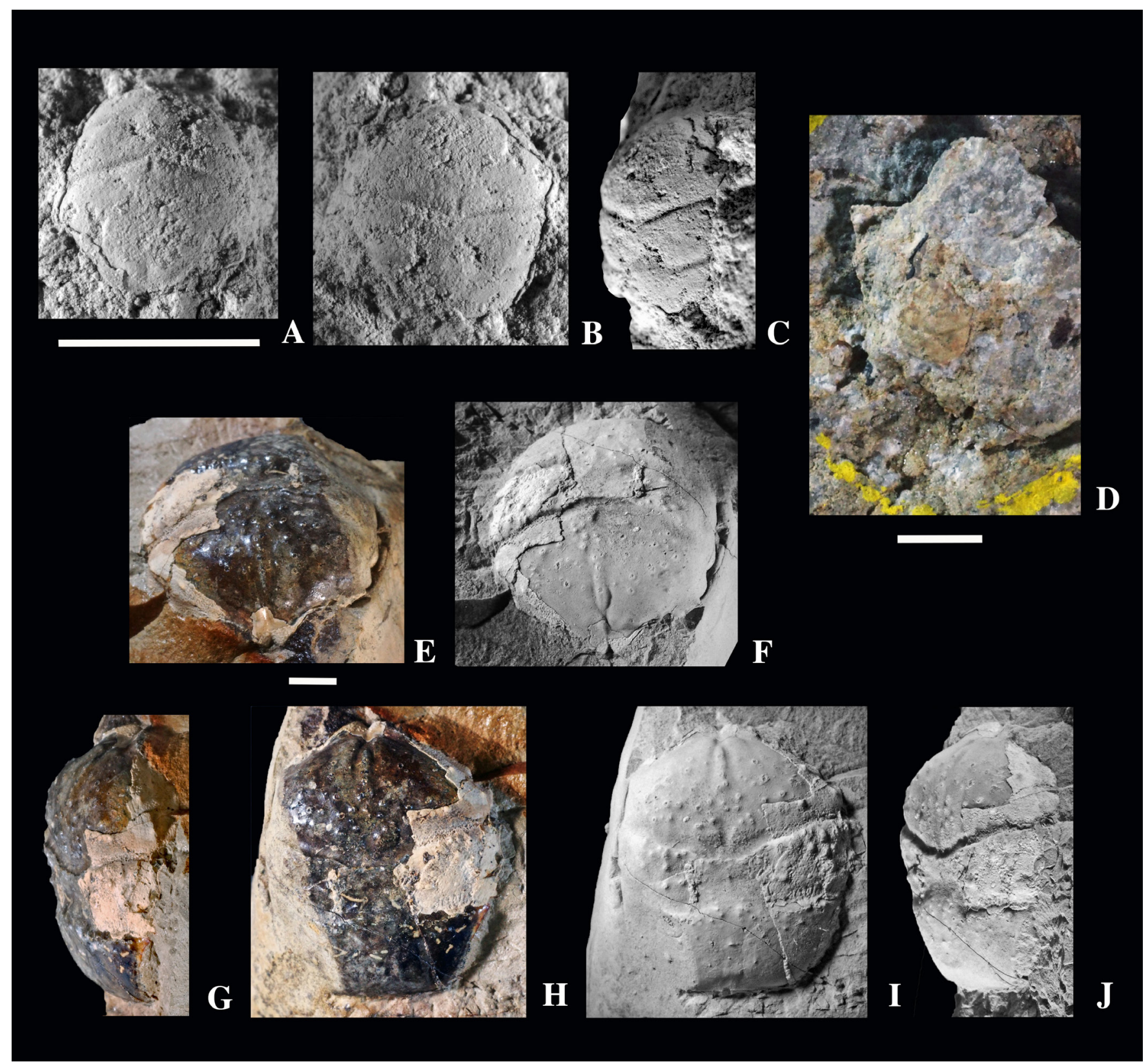

Figure 2 A-D, Goniodromites sp., MCM-M395, carapace, Tenkaritoge Formation (middle Cenomanian). E-J, Sabellidromites inflata (Collins and Karasawa, 1993), MFM247135, carapace, Osoushinai Formation (lower Campanian). A, E, F, oblique-frontal; B, D, H, I, dorsal; C, G, J, lateral view. A-C, F, I, and J are whitening images coated with ammonium chloride sublimate. Scale bars $=5 \mathrm{~mm}$. 
Discussion: Sabellidromites inflata, a quite rare goniodromitid species has been known by the holotype (TMNH01530 deposited in the Toyohashi Museum of Natural History). Collins and Karasawa (1993) originally assigned this species to Pithonoton Meyer, 1842. Subsequently, Schweitzer and Feldmann (2007) moved Pithonoton inflatum to the new genus Sabellidromites. Therefore, the revised diagnosis and description of this species placed in Sabellidromites are provided by examination of the holotype and the additional specimen herein figured.

Collins and Karasawa (1993) supposed that the stratigraphic horizon of this species was the Upper Cretaceous (Cenomanian to Campanian) based upon the co-occurrence of Gaudryceras sp., an ammonoid showing a wide stratigraphic distribution in the Cretaceous deposits of Hokkaido. A discovery of the second specimen from the Osoushinai Formation of the Upper Yezo Group suggests that the stratigraphic range for this species is restricted to the lower Campanian.

\section{Acknowledgements}

We thank K. Masuda (Chiba) for offering the second specimen of Sabellidromites and F.J. Vega (Instituto de Geología, Universidad Nacional Autónoma de México) for assisting in our manuscript. We are grateful for the reviews by A. Garassino (Department of Earth and Biological Sciences, Loma Linda University, USA) and F.J. Vega. This work is dedicated to the late colleague, G. Breton (formerly Université de Rennes I, France).

\section{References}

Agirrezabala, L.M., Kiel, S., Blumenberg, M., Schäfer, N., Reitner, J., 2013, Outcrop analogues of pockmarks and associated methane-seep carbonates: a case study from the Lower Cretaceous (Albian) of the Basque-Cantabrian Basin, western Pyrenees: Palaeogeography, Palaeoclimatology,
Palaeoecology, 390, 94-115. https://doi. org/10.1016/j.palaeo.2012.11.020

Beurlen, K, 1932, Brachyurenreste aus dem Lias von Bornholm mit Beiträgen zur Phylogenie und Systematik der Brachyuren Dekapoden: Paläontologische Zeitschrift, 14, 52-66. https://doi.org/10.1007/ BF03041617

Bishop, G.A., Williams, A.B., 2000, Fossil crabs from Tepee Buttes, submarine seeps of the late Cretaceous Pierre Shale, South Dakota andColorado, U.S.A.:Journalof Crustacean Biology, 20 (2), 285-300. https://doi. org/10.1163/1937240X-90000031

Campbell, K.A., 2006, Hydrocarbon seep and hydrothermal vent paleoenvironments and paleontology: Past developments and future research directions: Palaeogeography, Palaeoclimatology, Palaeoecology, 232, 362-407. https://doi.org/10.1016/j. palaeo.2005.06.018

Collins, J.S.H., Kanie, Y., Karasawa, H., 1993, Late Cretaceous crabs from Japan: Transactions and Proceedings of the Palaeontological Society of Japan, new series, 172, 292-310. https://doi. org/10.14825/prpsj1951.1993.172_292

Collins, J.S.H, Karasawa, H., 1993, The Cretaceous crab, Pithonoton inflatum from Hokkaido, Japan: Science Reports of The Toyohashi Museum Natural History, 3, 17-20.

Funaki, H., Hirano, H., 2004, Cretaceous stratigraphy in the northeastern part of the Obira area, Hokkaido, Japan: Bulletin of the Mikasa City Museum, Natural Science, 8, 17-35.

Glaessner, M.F., 1929, Crustacea Decapoda, in Pompeckj, FJ. (ed.), Fossilium catalogus, 1: Animalium, vol. 41: Berlin, W. Junk, 464 p. Hryniewicz, K., Amano, A., Bitner, M.A., Hagström, J., Kiel, S., Klompmaker, A.A., Mörs, T., Robins, G.M., Kaim, A., 2019, A late Paleocene fauna from shallow-water chemosynthesis-based ecosystems, Spitsbergen, Svalbard: Acta 
Palaeontologica Polonica, 64 (1), 101-141. https://doi.org/10.4202/app.00554.2018

Kaim, A., Jenkins, R., Warén, A., 2008, Provannid and provannid-like gastropods from the Late Cretaceous cold seeps of Hokkaido (Japan) and the fossil record of the Provannidae (Gastropoda: Abyssochrysoidea): Zoological Journal of the Linnean Society, 154, 421-443. https://doi. org/10.1111/j.1096-3642.2008.00431.x

Kanie, Y., Kuramochi, T., 1996, Description on possibly chemosynthetic bivalves from the Cretaceous deposits of Obira-cho, northwestern Hokkaido: Science Report of the Yokosuka City Museum, 44, 63-68.

Kanie, Y., Yoshikawa, Y., Sakai, T., Kuramochi, T., 1996, Cretaceous chemosynthetic fauna from Hokkaido: Science Report of the Yokosuka City Museum, 44, 69-74.

Karasawa, H., 2011, New axiidean Decapoda from the Albian (Lower Cretaceous) chemosynthetic community of Hokkaido, Japan: Bulletin of the Mizunami Fossil Museum, 37, 27-29.

Karasawa, H., Hayakawa, H., 2000, Additions to Cretaceous decapod crustaceans from Hokkaido, Japan: Part 1. Nephropidae, Micheleidae and Galatheidae: Paleontological Research, 4, 139-145. https://doi.org/10.2517/prpsj.4.139

Karasawa, H., Kato, H., 2007, New prosopid crabs (Crustacea, Decapoda, Brachyura) from the upper Jurassic Torinosu Group, Shikoku, Japan: Memoire della Società italiana di Scienze naturali e del Museo civico di Storia naturale di Milano, 35, 62-65.

Kiel, S., 2013, Lucinid bivalves from ancient methane seeps: Journal of Molluscan Studies, 79, 346-363. https://doi.org/10.1093/ mollus/eyt035

Kiel, S., Amano, K., Jenkins, R.G., 2008, Bivalves from Cretaceous cold-seep deposits on Hokkaido, Japan: Acta Palaeontologica Polonica, 53, 525-537. http://dx.doi. org/10.4202/app.2008.0310
Kiel, S., Hansen, B.T., 2015, Cenozoic MethaneSeep Faunas of the Caribbean Region: PLoS ONE, 10(10), e0140788. https://doi. org/10.1371/journal.pone.0140788

Kiel, S., Hybertsen, F., Hyžný, M., Klompmaker, A.A., 2020, Mollusks and a crustacean from early Oligocene methane-seep deposits in the Talara Basin, northern Peru: Acta Palaeontologica Polonica, 65, 109-138. https://doi.org/10.4202/app.00631.2019

Klompmaker, A.A., Feldmann, R.M., Schweitzer, C.E., 2012, A hotspot for Cretaceous goniodromitids (Decapoda: Brachyura) from reef associated strata in Spain: Journal of Crustacean Biology, 32, 780-801. https:// doi.org/10.1163/193724012X635340

Meyer, H. von, 1842, Über die in dem dichten Jurakalk von Aalen in Würtemburg vorkommenden Spezies des Crustaceengenus Prosopon: Beiträge zur Petrefaktenkunde, 5, 70-75.

Nyborg, T., Garassino, A., Ross, R.L.M., 2020, A new dromioid crab from the late Campanian of Hornby Island, Canada: Neues Jahrbuch für Geologie und Paläontologie Abhandlungen, 295 (2), 141-147. https:// doi.org/10.1127/njgpa/2020/0878

Ogihara, S., 2005, The evolution of chemosynthetic biological community at the site of cold-seep carbonate precipitation: Fossils, 78, 40-46. https://doi.org/10.14825/kaseki.78.0_40

Ogihara, S., 2008, Acyclic hydrocarbons and ketones in cold-seep carbonates from central Hokkaido, northern Japan: Geochemical Journal, 42,421-427.https: / / doi. org/10.2343/geochemj.42.421

Osanai, H., Mikami, K., Takahashi, K., 1960, Kyowa. 1-50,000. Explanatory of the Geological Map of Japan: Geological Survey of Hokkaido, 59 p.

Passy, A., 1832, Description géologique du département de la Seine-inférieure: Nicétas Periaux, Rouen, $371 \mathrm{p}$.

Rathbun, M.J., 1917, New species of South Dakota Cretaceous crabs: Proceedings of the U.S. 
National Museum, 52, 385-391. https:// doi.org/10.5479/si.00963801.52-2182.385

Reuss, A.E., 1858, Über kurzschwänzige Krebse im Jurakalke Mährens: Sitzungsberichte der Kaiserlichen Akademie der Wissenschaften, (Mathematisch-Naturwissenschaftliche Classe), 31, 5-13.

Schweitzer, C.E., Feldmann, R.M., 2007, A new classification for some Jurassic Brachyura (Crustacea: Decapoda: Brachyura: Homolodromioidea): families Goniodromitidae Beurlen, 1932 and Tanidromitidae new family: Senckenbergiana lethaea, 87(2), 119-155. https://doi.org/10.1007/BF03043911

Schweitzer, G.E., Feldmann, R.M., Garassino, A., Karasawa, H., Schweigert, G., 2010, Systematic list of fossil decapod crustacean species: Crustaceana Monographs, 10, $1-222$.

Schweitzer, C.E., Feldmann, R.M., and Karasawa, H., 2012, Part R, Revised, Volume 1, Chapter 8M: Systematic descriptions: Infraorder Brachyura, Section Dromiacea: Treatise Online, 51, 1-43. https://doi.org/10.17161/to.v0i0.4336

Takahashi, A., Hirano, H., Sato, T., 2003, Stratigraphy and fossil assemblage of the Upper Cretaceous in the Teshionakagawa area, Hokkaido, northern Japan: The Journal of the Geological Society of Japan, 109, 77-95. https://doi.org/10.5575/ geosoc. 109.77

Tanabe, K., Hirano, H., Matsumoto, T., Miyata, Y., 1977, Stratigraphy of the Upper Cretaceous deposits in the Obira area, northern Hokkaido: Memoirs of the Faculty of Science, Kyūsyū University. Series D, Geology, 12, 181-202.

Wright, G.W., Wright, E.V., 1950, Some dromiacean crabs from the English Cretaceous: Proceedings of the Geologists' Association, 61, 13-27. https://doi. org/10.1016/S0016-7878(50)80009-3

Yabe, H., 1904, Cretaceous Cephalopoda from the Hokkaidō. Part 2. Turrilites, Helicoceras, Heteroceras, Nipponites, Olcostephanus, Desmoceras, Hauericeras, and an undetermined genus: Journal of the College of Science, Imperial University of Tokyo, 20, 1-45. 